\title{
Impact of the Local Authority Transfer Fund (LATF) on Service Delivery: Perspectives from the County Council of Garissa, Kenya
}

\author{
Samwel Mosomi Mogeni \\ Part Time Lecturer, Kenyatta University, Kenya \\ The School of Business Kenyatta University, Kenya
}

\begin{abstract}
This paper interrogates the impact of LATF on service delivery and draws illustrations from the county council of Garissa in Kenya. Its point of departure is the strengthening of LAS by the Kenyan government to deliver services introduced the LATF in 1999, increasing the allocation to the fund from Shs.1b in FY 1999/2000 to Ksh.7.5b in FY 2006/07. The County Council of Garissa allocation increased from Kshs 4,052,720.00 in 1999/2000 to Kshs 50,153,956.00 in 2006/2007. The paper used structured and semistructured questionnaires to the respondents the data collected were analyzed using descriptive statistics where percentages based on frequencies were calculated. The paper found out that after the introduction of LATF, the quality of services offered improved and the council was able to offer additional services according to seventy-six percent of the respondents, while it did not for twenty-four percent of the respondents. With the exception of reservations from twenty-four percent of the respondents, the paper concludes that LATF has enabled the council to offer additional services and improve the quality of its services.
\end{abstract}

Keywords: LATF, LAS, Local authorities, LATF Act, Garissa

\section{Introduction}

This paper takes as its point of departure the perspectives and the needs that necessitated the establishment of the Local Authority Transfer Fund (LATF). It is significant to note that LATF was established by the enactment of LATF Act No. 8 of 1998 as a grant from Kenya's central government to the local authorities for the primary purpose of enabling the local authorities to extend and improve services to their residents. LATF is supposed to be $5 \%$ of the annual income tax revenue.

According to the Act, LATF was created with three key objectives. To enable local authorities to improve local service delivery to the public, to improve financial management, revenue mobilization and accountability in local authorities and to eliminate all outstanding debts owed by local authorities within five years of the act becoming operational (2000-2005).

As the paper insinuates from the foregoing, LATF has three components:

a) Service Delivery - which constitutes sixty percent of the total LATF allocation. This amount is exclusively meant for service delivery projects identified within a given local Council area.

b) Performance- which constitutes forty percent of the total LATF allocation. This component is aimed at catering for administrative costs that help the respective local authority enhance its capacity in financial management (e.g., training of finance officers, purchase of equipment and facilities, etc.) revenue collection, and minimizing and eventually eliminating the perennial debts owed by Councils.

There is a third component of LATF that was only available to a few Councils referred to as transitional Component. It was aimed at boosting Councils that receive less income from LATF than from the abolished local authority service charge. However, this component was meant to continue for only three years when LATF became operational, it has since been abolished.

Local Authorities have been the target of focused intervention to improve local economic governance, transparency and accountability. Through the LATF mechanism, local authorities are expected to improve their local service delivery and financial management through submitting improved budgets, financial accounts, debt resolution plans, local revenue enhancement plans, and local authority service delivery plans in order to annually receive the LATF monies (MLG/Circular No. 9/2003)

The LATF is disbursed in three installments within each financial year depending on individual Local Authorities' (LAs) compliance with key criteria relating to financial reporting, service delivery and participatory planning(MLG/Circular No. 9/2003).

An advisory committee comprising the private sector, the Ministry of Finance, the Permanent Secretary Ministry of Local Government, and the Kenya Local Government Reform Programme's secretariat, guides LATF operations. LATF annual reports and other disbursement information are disseminated through newspaper advertisements.

Since $1999 / 2000$, there has been a considerable increase in the amounts disbursed through LATF as analyzed hereunder: - 


\section{International Journal of Science and Research (IJSR) \\ ISSN (Online): 2319-7064}

Index Copernicus Value (2015): 78.96 | Impact Factor (2015): 6.391

Table 1.1: LATF monies disbursed to local authorities

\begin{tabular}{|l|l|}
\hline Financial year & Amount disbursed \\
\hline & Ksh. Billions \\
$1999 / 2000$ & 1.0 \\
$2000 / 2001$ & 2.3 \\
$2001 / 2002$ & 3.0 \\
$2002 / 2003$ & 3.0 \\
$2003 / 2004$ & 3.75 \\
$2004 / 2005$ & 4.0 \\
$2005 / 2006$ & 5.0 \\
$2006 / 2007$ & 7.5 \\
\hline
\end{tabular}

(Source: LATF Database)

The introduction I have so far given provides a background to the introduction of the concept LATF in county councils. In the following paragraph, the paper provides a background to the county council of Garissa.

The County Council of Garissa is the grassroots democratic level of Governance in Garissa District. Its origin can be traced back in 1926 when the first settlements were created along Ganana River, presently known as Tana River. At this time an old man from the Oromo tribe Called Garissa was farming along Ganana River. White men visited the area and named the place after the farmer "Garissa". The County Council of Garissa started as African District Council (ADC) of the colonial era which later on after independence. County Council of Ijara was heaved upon creation of Ijara District (Council database). The Council has 31 permanent employees and 31 Councillors. The clerk is the chief officer. The clerk and the treasurer are the two key accounting officers who are responsible for overseeing the budget, revenues and expenditures and the general administration of the Council.

\section{Service Delivery in the Old System and the New System}

To achieve the objective of the paper, questionnaires were given to 34 respondents, 32 of whom filled and returned the questionnaires. Of the 32 questionnaires returned, 29 were properly filled and hence used for the study. The response rate of $85 \%$ was considered adequate for the purposes of the study.

This section presents findings on the services that were offered before and after the introduction of LATF, whether there has been improvement in service delivery and limiting factors and possible solutions on improvement of service delivery.

\subsection{Services offered before and after introduction of LATF}

The table (1.2) below, presents the list of the services that were offered by the council before and after the introduction of LATF.
Table 1.2: Services offered before and after introduction of LATF

\begin{tabular}{|c|c|c|}
\hline Service & Before & After \\
\hline Garbage collection & & \\
\hline Maintenance of Markets & & \\
\hline Education (nursery school teachers\& bursaries) & & \\
\hline water supply & & \\
\hline Health Service (dispensaries) & & \\
\hline Irrigation services & & \\
\hline Construction of classrooms & & \\
\hline Supply of desks/textbooks to schools & & \\
\hline Electrification of schools & & \\
\hline HIV/AIDS awareness & & \\
\hline
\end{tabular}

From table 1.2 above it can be deduced that;

- Before the introduction of LATF major services that the council offered included garbage collection, Maintenance of markets, provision of education services and facilitation of water supply.

- After the introduction of LATF, the council started offering additional services. The major ones being construction of classrooms and dispensaries, purchase of water pumps for irrigation purposes, supply of desks/textbooks to schools, electrification of schools and HIV/AIDS awareness.

- With the introduction of LATF the Council has more funds which have enabled it to offer more services. Pegged on more services, the objective of LATF of improvement on service delivery has been met. However, the impact felt by the residents can be assessed through another study.

\subsection{Quality of services offered by the council}

\section{(i) Improvement on service delivery}

The study sought to find out whether there has been an improvement in service delivery after the introduction of LATF. As analyzed in table 4.2 below, there has been an improvement according to $76 \%$ of the respondents while $17 \%$ feel that there's no improvement and the rest $(7 \%)$ are indifferent. LATF can therefore be said to have had a positive impact on improving service delivery

Table 1.3: Respondents rating of improvement in service delivery

\begin{tabular}{|c|c|c|}
\hline Quality of service & $\mathrm{N}$ & $\%$ \\
\hline Improved & 22 & 75.90 \\
\hline Not improved & 5 & 17.30 \\
\hline Do not know & 2 & 6.90 \\
\hline Total & 29 & 100.00 \\
\hline
\end{tabular}

From these findings, the paper can establish that the services whose delivery has improved and why the respondents felt so. The findings are analyzed in table 1.4 below:-

Table 1.4: Services that have improved after introduction of LATF

\begin{tabular}{|c|c|c|}
\hline Service & $\mathrm{n}$ & $\%$ \\
\hline Construction of classrooms & 22 & 75.90 \\
\hline Construction of dispensaries & 20 & 70.00 \\
\hline Maintenance of markets & 19 & 65.50 \\
\hline Water pumps for irrigation & 17 & 40.60 \\
\hline Electrification of schools & 17 & 38.60 \\
\hline HIV/AIDS awareness & 11 & 37.90 \\
\hline
\end{tabular}




\section{International Journal of Science and Research (IJSR) \\ ISSN (Online): 2319-7064}

Index Copernicus Value (2015): 78.96 | Impact Factor (2015): 6.391

The respondents further explained their perceived improvement on service delivery as summarized below:-

\subsubsection{Construction of classrooms}

A number of classrooms in different schools had been put up. There has been enhanced enrollment and access to education improving the literacy levels among school going children.

\subsubsection{Construction of dispensaries}

A number of dispensaries constructed, some have been staffed and operationalized by Ministry of public health and sanitation. More residents have access to medical services.

\subsubsection{Maintenance of markets}

Bringing markets closer to the residents which facilitate trade.

\subsubsection{Water pumps for irrigation}

Increase food production and hence food security for residents.

\subsubsection{Electrification of schools}

Improving learning conditions and hence literacy levels.

\subsubsection{HIV/AIDS awareness}

Reducing HIV/AIDS transmission and its better management of those infected. This enhances productivity of the residents.

\section{(ii) Limiting factors on service delivery}

The paper argues that there are people who feel that introduction of LATF has not led to improvement in service delivery. The limiting factors (Table 1.5) and ways of overcoming them as given are analyzed below:-

Table 1.5: Factors hindering improvement in service delivery

\begin{tabular}{|c|c|c|}
\hline Limiting factor & $\mathrm{n}$ & $\%$ \\
\hline Failure to adhere to the budget & 2 & 33.30 \\
\hline Mismanagement of council funds & 4 & 66.70 \\
\hline Insufficient funds allocated to projects & 4 & 66.70 \\
\hline Lack of action on officers who misuse funds & 4 & 66.70 \\
\hline Poor planning & 3 & 60.00 \\
\hline
\end{tabular}

From the results in table 1.5 above, inadequate funds for projects, mismanagement of council funds and lack of action on those responsible rank first on the limiting factors followed by inadequate funds, poor planning and non adherence to the budget.

\subsection{Participation and involvement of residents in project identification}

The study also sought to find the extent to which the residents of the County Council of Garissa are involved in identification of capital projects to be undertaken and the effectiveness of LASDAP. The findings are analyzed in 1.5.1 and 1.5.2 below:-
2.3.1 Holding of LASDAP meetings and involvement of residents in project identification

Table 1.6: Holding of LASDAP meetings to identify projects to be undertaken

\begin{tabular}{|c|c|c|}
\hline $\begin{array}{c}\text { LASDAP Meetings held and } \\
\text { identified projects are prioritized }\end{array}$ & $\mathrm{n}$ & Percentage \\
\hline Agree & 26 & 89.65 \\
\hline Disagree & 3 & 10.35 \\
\hline Total & 29 & 100.00 \\
\hline
\end{tabular}

From table 1.6 above, $90 \%$ of the respondents agreed that the annual LASDAP consultative meetings are held at ward levels to identify projects to be undertaken. Further they agreed that in most cases the prioritized projects are as identified during the LASDAP meetings. In addition the respondents identified NGO's, religious groups, Community based organizations, provincial administration and the other residents as those who usually participate in the consultative meetings. $10 \%$ of the respondents however said that residents are not involved in identification of projects to be undertaken by the council. According to them it's done by only the chief officers and councilors. Most of the respondents in this category were junior council officers. From the results, residents are involved in identification of projects to be undertaken. However, more awareness is needed to bring on board all the residents.

\subsubsection{Effectiveness of LASDAP}

Table 1.7: Effectiveness of LASDAP in identifying projects to be undertaken

\begin{tabular}{|c|c|c|}
\hline $\begin{array}{c}\text { LASDAP is an effective way of } \\
\text { identifying projects to be undertaken }\end{array}$ & $\mathrm{n}$ & Percentage \\
\hline Agree & 27 & 93.00 \\
\hline Disagree & 2 & 7.00 \\
\hline Total & 29 & 100.00 \\
\hline
\end{tabular}

$93 \%$ of the respondents were of the opinion that LASDAP is an effective way of identifying projects that are of priority to the community to be undertaken. This is because residents are best placed to know areas that are of greater social economic importance for their well being. However 7\% of the respondents felt that it's not effective as funds allocated are usually inadequate and so many small projects that have little impact end up being identified and partially undertaken. Even though LASDAP is an effective way of identifying projects, it's critical that they are advised to go for few but large projects with a greater social-economic impact.

\section{Budget Management}

In order to examine the impact of the introduction of LATF to the county council of Garissa, the paper had to look into the issue of budget. The extent to which the council adheres to the budgetary process was analysed and the findings are as follows:-

\subsection{Preparation and submission of budget on time}

All the respondents agreed that the council's budget is prepared and submitted in time. This has resulted to the

\section{Volume 6 Issue 7, July 2017 www.ijsr.net}




\section{International Journal of Science and Research (IJSR) \\ ISSN (Online): 2319-7064}

Index Copernicus Value (2015): 78.96 | Impact Factor (2015): 6.391

Council not suffering any penalty for late submission of the annual budget thereby boosting its financial position. With the council receiving all funds it's in a position to offer all budgeted for services.

\subsection{Implementation and completion of capital projects}

Table 3.1 below summarises findings on implementation and completion of capital projects.

Table 3.1: Implementation and completion of projects

\begin{tabular}{|c|c|c|}
\hline Frequency & $\mathrm{n}$ & $\%$ \\
\hline Always & 9 & 31.00 \\
\hline Sometimes & 18 & 62.10 \\
\hline Never & 2 & 6.90 \\
\hline Total & 29 & 100.00 \\
\hline
\end{tabular}

From table $3.1,62 \%$ of the respondents feel that though the council strives to implement and complete projects, it's not always done, compared to $31 \%$ who agree that projects are always implemented and completed. $7 \%$ reported that projects are not implemented at all. It appears that the concerned authorities should put mechanisms in place to ensure that budgeted for projects are undertaken. Hence residents will enjoy benefits that will accrue from implementation of the projects.

\subsection{Adherence to LATF budget and effect of LATF in boosting Council's finances}

The paper also sought the respondent's views on the Council's adherence to the LATF budget and whether LATF has boosted the council financially. The findings are tabulated in table 3.3 and table 3.4 below respectively.

Table 3.3: Extent to which the council adheres to the approved LATF budget

\begin{tabular}{|c|c|c|}
\hline Extent & $\mathrm{n}$ & $\%$ \\
\hline Always & 2 & 6.90 \\
\hline Sometimes & 14 & 48.30 \\
\hline Never & 13 & 44.80 \\
\hline Total & 29 & 100.00 \\
\hline
\end{tabular}

According to $48.3 \%$ of the respondents, the council does not always adhere to the LATF budget. The council never adheres to the LATF budget according to $44.8 \%$ of the respondents, with $6.9 \%$ agreeing that the council always adheres to its LATF budget.

From the findings, the council does not adhere to its budget implying that not all budgeted for projects are implemented. To this end, relevant authorities are supposed to ensure total compliance with approved budget.

Table 3.4: Impact of LATF on council's financial position

\begin{tabular}{|c|c|c|}
\hline Extent & $\mathrm{n}$ & $\%$ \\
\hline Disagree & 1 & 3.40 \\
\hline Neutral & 4 & 13.80 \\
\hline Agree & 24 & 82.80 \\
\hline Total & 29 & 100.00 \\
\hline
\end{tabular}

From table $3.4,83 \%$ of the respondents agree that LATF has boosted the council's financial position. Hence the council, due to LATF is in a position to offer more and better services.

\subsection{Monitoring}

The study also sought to find out whether the LATF is regularly audited by both internal and external auditors and whether it's improving the council's financial management and hence service delivery.

\subsubsection{Regularity of audits}

Table 3.5.1 and 3.5.2 below, present findings on the frequency of internal and external audits.

Table 3.5.2: Frequency of internal audits

\begin{tabular}{|c|c|c|}
\hline Frequency & $\mathrm{n}$ & $\%$ \\
\hline Never & 25 & 86.20 \\
\hline Sometimes & 3 & 10.30 \\
\hline Always & 1 & 3.50 \\
\hline Total & 29 & 100.00 \\
\hline
\end{tabular}

According to majority of the respondents $(86 \%)$, internal audit is never done, while it's sometimes done according to $10 \%$ of the respondents. Only $4 \%$ of the respondents agree that internal auditing is always done.

Table 4.11: Frequency of external audits

\begin{tabular}{|c|c|c|}
\hline Frequency & $\mathrm{n}$ & $\%$ \\
\hline Never & 1 & 3.40 \\
\hline Sometimes & 4 & 13.80 \\
\hline Always & 24 & 82.80 \\
\hline Total & 29 & 100.00 \\
\hline
\end{tabular}

From the table (4.11), majority of the respondents $(82.80 \%)$ agree that external audits are always done.

\subsection{Value of audits to management of LATF}

The respondents' views on the importance of audit on better management of LATF were sought. Findings are analyzed in table 4.12 below:-

Table 3.6: Value of audit for better management of LATF

\begin{tabular}{|c|c|c|}
\hline Has value & $\mathrm{n}$ & $\%$ \\
\hline Yes & 16 & 55.20 \\
\hline No & 13 & 44.80 \\
\hline Total & 29 & 100.00 \\
\hline
\end{tabular}

From table $3.6,55 \%$ of the respondents agree that audits are of value to better management of LATF and hence service delivery while $45 \%$ of the respondents however disagree.

\section{Conclusion}

Following the foregoing argument, this paper concludes by arguing that the introduction of LATF has led to more and improved services offered by the County Council of Garissa. The factors contributing to this conclusion include:-

1) The offering of additional services after the introduction of LATF. The additional services include construction of classrooms and dispensaries, electrification of schools, supply of desks/textbooks to schools and HIV/AIDS awareness programme. 
2) The improvement of services offered to the residents after the introduction of LATF.

3) The involvement of residents through LASDAPS in the identification of projects to be undertaken using LATF funds.

4) Preparation and submission of an annual budget complying with requirements in time. This ensures the council receives it's budgeted for funds in full.

5) Carrying out of regular external audits. This reports on non-compliance with financial regulations and hence corrective action recommended.

\section{References}

[1] Bahl, R.W and Linn, F.(1992). Urban Public Finance in Developing Countries New York:, Oxford: Oxford University Press

[2] Devas N. (2002). Local Government DecisionMaking:Citizen Participation and Local Accountability (DFID)International Development Department, Birmingham: University of Birmingham Press

[3] Devas, N. and Grant U. (2003). Local government decision making-citizen participation and local accountability:http:www:abckabissa.org.

[4] Evans, H. (1992). A virtuous cycle model of RuralUrban Development: Evidence from a KenyanSmall Town and its Hinterland, Journal of Development Studies Vol. 28, No. 4.

[5] Hepworth, N. (1980). The finance of local government, $6^{\text {th }}$ ed London; George Allan Unwin.

[6] Hyden, G., Jackson R., and Okumu J. (1970). Development Administration. The Kenya experience. Nairobi. Nairobi:Oxford University Press.

[7] Kee, S. (1997). Fiscal Decentralization and Economic Development, Public finance quarterly, vol. 5, No. 1.

[8] Republic of Kenya (2005-2006). LATF Annual report. Nairobi: Government Printing Press.

[9] Smoke, P. (1994). Local Government Finance in Developing Countries. The case Paper of Kenya, Nairobi: Oxford University Press.

[10] Nyaloti, E. (2005). The Local Government Act: A critique. Nairobi: Government Printing Press.

[11] Wekwete, C. (1992). Urban Local Government Finance in Zimbabwe. The case of Harare City Council Public Administration and Development Vol. 12 , No.1

[12] World Bank. (2002). An Assessment of Local Service Delivery and Local Government in Kenya.

[13] Wunsch, J. and Olowu, D. (1990). The failures of the centralized state. Institution and self-governance in Africa. Boulder, Co. West view press 